\title{
Separation and some properties of temperature sensitive fraction in casein
}

\author{
Yasuo Igarashi and Zen-ichi Sarto
}

(Faculty of Agriculture, Hirosaki University)

(Received for publication on October 11, 1967)

Chromatographic procedures using DEAE- or TEAE-cellulose columns have often been used for the fractionation of milk proteins. Several investigators reported the separation of $\alpha_{s}-, \beta_{-}$ and $k$-casein by column chromatography with buffer systems sometimes containing dissociation agents such as urea ${ }^{7,10)}$, and 2 -mercaptoethanol ${ }^{10)}$. However, most ignored the fraction which was not adsorbed on the columns and represented the first peak of the chromatograms. Groves et $a l .{ }^{21}$ reported that the fraction was temperature sensitive. Otherwise information about this fraction is lacking.

The present paper describes a chromatographic procedure for the preparation of the temperature sensitive fraction (TSF) from acid casein, and some properties of the isolated fraction.

\section{Materials and Methods}

Preparation of acid casein:

Skim milk prepared from fresh, raw, pooled milk as described elsewhere ${ }^{3)}$ was warmed to $37^{\circ} \mathrm{C}$ and acidified to $\mathrm{pH} 4.6$ by the dropwise addition of $5 \%$ acetic acid under gentle agitation. The precipitate which formed in the acidified skim milk was separated on a Buchner funnel, redispersed in distilled water (about the same volume as original skim milk), dissolved at $\mathrm{pH}$ 7.7 by the dropwise addition of IN $\mathrm{NaOH}$, reprecipitated, and dissolved again. Two washes with acidified water ( $\mathrm{pH} 4.5$ ) followed each precipitation procedure.

The final casein solution was adjusted to $\mathrm{PH} 8.0$ and dialyzed at $5^{\circ} \mathrm{C}$ against several changes of the buffer solution $(0.027 \mathrm{M} 2$-amino-2-methyl-1-propanol-0.0089 $\mathrm{M}$ citric acid, $\mathrm{pH} 8.0)$ for 24 hours. The dialyzed casein solution was centrifuged $\left(10,000 \mathrm{G}, 30 \mathrm{~min}\right.$ at $\left.1^{\circ} \mathrm{C}\right)$ to remove a trace of fatty substance and used as the casein solution for chromatography.

Column chromatography:

The chromatographic procedure described in previous paper $^{3 !}$ was used with slight modifications as follows: The casein solution (20ml containing $385 \mathrm{mg}$ of protein) applied on the TEAE cellulose column $(2.0 \times 15 \mathrm{~cm})$ was eluted at $1^{\circ} \mathrm{C}$ or $30^{\circ} \mathrm{C}$ with a concave gradient of 2 -amino-2methyl-1-propanol (AMP)-citric acid buffer. Six hundred $\mathrm{ml}$ of starting buffer (pH 8.0), $300 \mathrm{ml}$ of limiting buffer ( $\mathrm{pH} 6.6$ ) and $200 \mathrm{ml}$ of $0.2 \mathrm{~N} \mathrm{NaOH}$ was used. Additional elution with limiting buffer prior to the elution with $\mathrm{NaOH}$ was omitted. The composition of the buffer was slightly changed to ensure a proper $\mathrm{pH}$. It was $0.027 \mathrm{M}$ AMP-0.0089 $\mathrm{M}$ citric acid for starting buffer and 0.744 AMP- $0.255 \mathrm{M}$ citric acid for limiting buffer.

Starch gel electrophoresis:

Gel composition and the bridge solution were the same as described by WAke and BAWLDWIN ${ }^{11}$. Vertical electrophoresis was carried out in a cold room $\left(1^{\circ} \mathrm{C}\right)$ applying $1 \mathrm{~mA}$ / $1 \times 0.5 \mathrm{~cm}^{2}$. 
Preparation of TSF:

The casein solution ( $40 \mathrm{ml}$ containing $1.5 \mathrm{~g}$ of protein) was applied to the colum $(2.8 \times 15 \mathrm{~cm})$ and eluted with the starting buffer at $1^{\circ} \mathrm{C}$. The portion eluted with the starting buffer was rechromatographed under the same conditions. Thus TSF, which was clear in the cold but turbid at room temperature (above $20^{\circ} \mathrm{C}$ ) was obtained. Protein recoveries based on the absorbancy at $280 \mathrm{~m} \mu$ and $10 \%$ TCA-insoluble nitrogen were $5.1 \%$ and $4.7 \%$ of applied casein, respectively.

Treatment of TSF and measurement of turbidity:

The turbidity of TSF was examined at various temperatures and $\mathrm{pH}$ with a Hitachi EPU2A spectrophotometer at $610 \mathrm{~m} \mu$. The temperature of TSF contained in the glass cell of the spectrophotometer was adjusted by passing water from Yamato Coolnics through the wall of cell chamber. The $\mathrm{pH}$ of TSF was changed by the dropwise addition of $0.1-1 \mathrm{M}$ citric acid or 0.2-2M AMP. A Hitachi Horiba $\mathrm{pH}$ meter (type $\mathrm{M}-4$ ) equipped with needle type electrode was used to measure the $\mathrm{pH}$. To investigate the heat stability of TSF, it was heated in a test tube at $75^{\circ} \mathrm{C}$ for $15 \mathrm{~min}$ or $90^{\circ} \mathrm{C}$ for $10 \mathrm{~min}$ with subsequent cooling to $5^{\circ} \mathrm{C}$. The turbidity of the treated TSF was measured as described above.

Electron micrographs and absorption spectrum:

The shape of the particles in the turbid TSF was examined with a Hitachi HU-11B electron microscopy using chromium shadowing9). The absorption spectrum of TSF (in $0.1 \mathrm{~N} \mathrm{NaOH}$ ) was obtained with a Hitachi recording UV spectrophotometer. The tyrosine-tryptophane ratio was calculated from the spectrum by the method of Bencze and ScHMid ${ }^{11}$.

\section{Results}

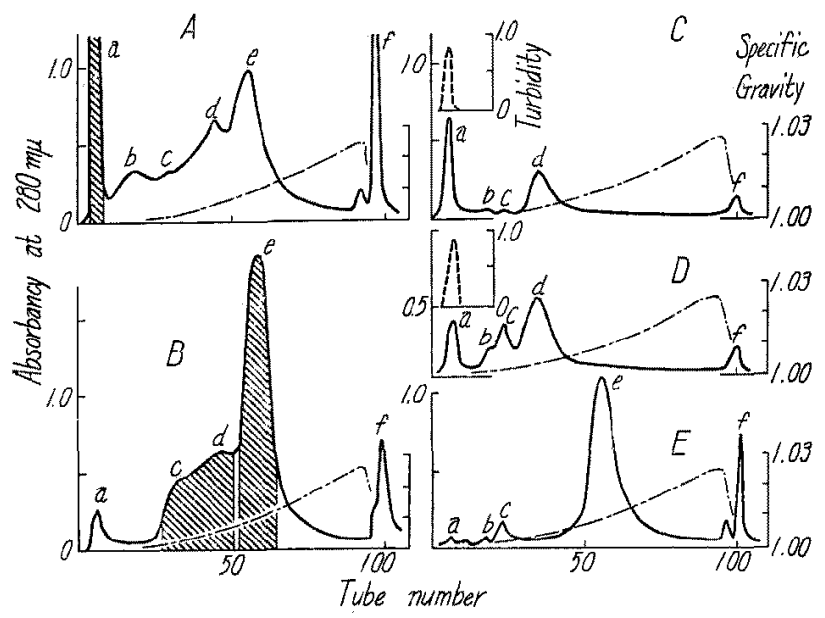

The hatched area was subjected to rechromatography. The gradient curve was extrapolated from specific gravity measurement of the effluents. Absorbancy at $280 \mathrm{~m} \mu$ was measured at 5 to $10^{\circ} \mathrm{C}$. Turbidity of TSF at $610 \mathrm{~m} \mu$ and $30^{\circ} \mathrm{C}$ is indicated by the broken line.

(A) and (B): Chromatograms of acid casein eluted at $1^{\circ} \mathrm{C}$ and $30^{\circ} \mathrm{C}$, respectively (C), (D) and (E): Rechromatograms of A-a, B-c, d and B-e, respectively.

Fig. 1. Chromatography of acid casein and subsequent rechromatography of some chromatographed fractions on TEAE cellulose column by gradient elution with AMP-citric acid buffer 


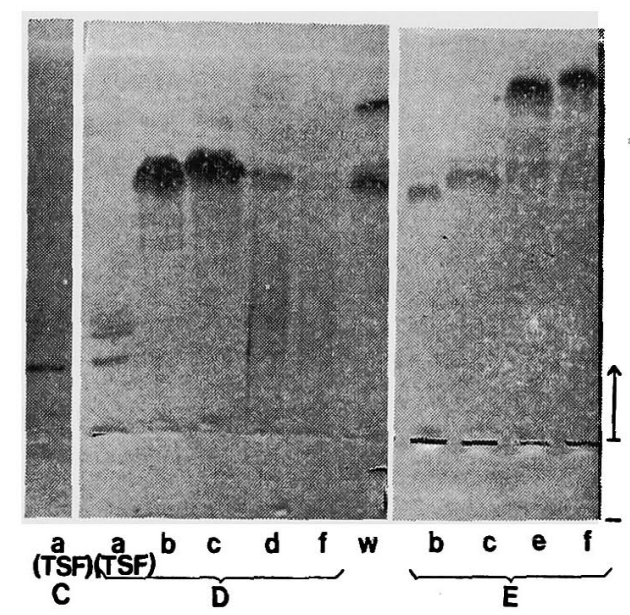

Fig. 2. Starch gel electrophoresis (pH 8.6, 7 $\mathrm{M}$ urea) of uhole casein (W) and various effluent fractions of Fig. 1

Chromatograms of acid casein eluted at $1^{\circ} \mathrm{C}$ and $30^{\circ} \mathrm{C}$ and subsequent rechromatograms of some of the chromatographed fractions are shown in Fig. 1. Peaks in the figures were identified by starch gel electrophoresis (Fig. 2). The first peak eluted at $1^{\circ} \mathrm{C}$ (Fig. 1-A) contained TSF, but did not demonstrate the characteristic property, i. e. temperature sensitivity of turbidity. This property, however, did appear after rechromatography (Fig. 1-C). On the other hand, the first peak eluted at $30^{\circ} \mathrm{C}$ did not contain TSF (Fig. 1-B). Rechromatography of peak $\mathrm{B}-\mathrm{c}, \mathrm{d}$ and B-e, demonstrated that TSF had existed in peak B-c,d together with $\beta$ - and $\kappa-$ casein (Fig. 2), and only separated from the other components on rechromatograph at $1^{\circ} \mathrm{C}$ (Fig. 1-D). Peak B-e containing $\alpha_{s}$-casein was not influenced by the temperature of elution, and seemed to have no direct relation to TSF.

The relation between turbidity and temperature of TSF at 3 levels of concentration is shown in Fig. 3. At the lowest concentration, the turbidity of TSF only appeared at a slightly

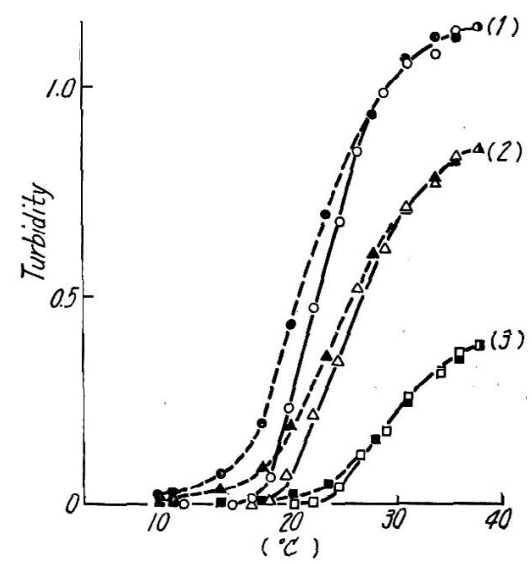

The soild lines and the dashed lines represent the turbidity obtained on warming and cooling, respectively.

Concentration: (1) $0.06 \%$, (2) $0.04 \%$, and (3) $0.02 \%$ protein (TCA-insoluble Kjeldahl $\mathrm{N} \times 6.38$ )

Fig. 3. Turbidity of TSF in buffer solution at $\mathrm{pH} 8.0$ as a responce to temperature at three levels of concentration 
higher temperature. The changes in turbidity were reversible and could be treated as phase transitions. The turbidity of TSF depended largely on $\mathrm{pH}$ as well as temperature (Fig. 4). A visible precipitate was always observed near $\mathrm{pH} 4.5$ regardless of temperature. The $\mathrm{pH}$ range, in which the protein of TSF precipitated, tended to expand at higher temperature. At the $\mathrm{pH}$

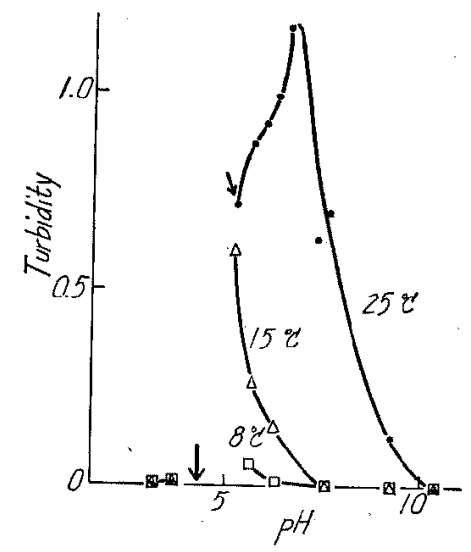

Arrows show the formation of visible precipitate

Fig. 4. Relation between the turbidity and $\mathrm{pH}$ for TSF

$\left(0.06 \%\right.$ protein) measured at 8,15 and $25^{\circ} \mathrm{C}$

ranges lower lower than 4 and higher than 10, TSF was clear at all reasonable temperatures. Heated TSF was compared with non-heated TSF in respect to reversible changes of turbidity (Fig. 5). Heat treatments caused decreases in the turbidity to a certain extent, but thereversibility of turbidity was not altered.

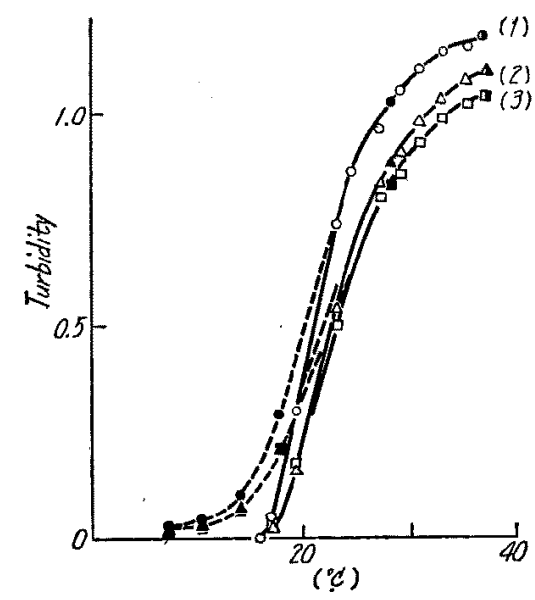

The $\mathrm{pH}$ of the samples were adjusted to 7.0 after the heat treatment. The solid lines represent the values obtained on warming and the dashed lines on cooling. (1) Control, (2) $75^{\circ} \mathrm{C} 15 \mathrm{~min}$, (3) $90^{\circ} \mathrm{C} 10 \mathrm{~min}$

Fig. 5. Fffect of heat treatment on the turbidity of TSF $(0.06 \%$ protein)

The electron micrograph of TSF, shows clearly defined particles that are almost spherical (Fig. 6). Since turbid TSF was used to prepare the electron microscopic specimen at room: temperature, the particles represent TSF in the turbid state. The absorption spectrum of TSF is shown in Fig. 7. The tyrosin-tryptophane molar ratio (calculated from the spectrum. was 2.55) was lower than the published data ${ }^{12}$ ) for caseins. 


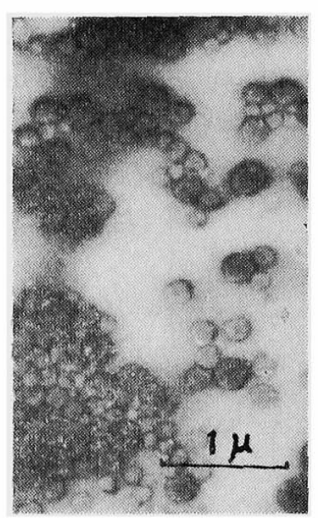

Fig. 6. Electron micrograph on TSF (in turbid state) in distilled water

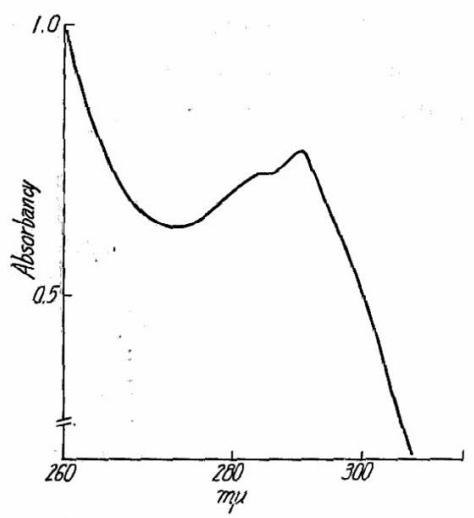

FIg. 7. Absorption spectrum of TSF in $0.1 \mathrm{~N}$ $\mathrm{NaOH}$

\section{Discussion}

Separation of TSF from other proteins in acid casein was achieved by column chromatography at low temperature $\left(1^{\circ} \mathrm{C}\right)$. The property of formation of colloidal globules at room temperature, resulting in turbidity, is rather unusual in comparison with other milk proteins. However, a similar property was reported for tobacco-mosaic virus protein by LAUFFER ${ }^{5)}$. The tyrosintryptophane ratio and electrophoretic property as well as the temperature sensitivity demonstrated that TSF differed from casein components already reported. The temperature sensitivity is probably caused by the association-dissociation of relatively small proteins through weak bonds such as hydrophobic bonds.

The temperature dependent association of $\beta$-casein is well known. RosE and CoLviN ${ }^{81}$ observed that casein micelles from warm milk differ in electron microscopic appearance from those of cold milk. They explained it as follows: $\beta$-casein, which existed finely dispersed in the cold, deposited on the surface of the micelles when the milk was warmed to $35^{\circ} \mathrm{C}$, and tended to link small micelles into clumps and strings, because $\beta$-casein is the only major component of milk known to vary in solubility or dispersing ability over this temperature range. The present paper, however, demonstrates that there is another component, i.e. TSF, which associates or dissociates on change of temperature. PAYENS ${ }^{61}$ ascribed the thermal association of casein to hydrophobic interaction and this type of interaction would also account for the characteristic property of TSF.

The association-dissociation property of TSF and the effect of temperature on elution position of TSF on chromatography suggested the possibility that TSF also associates with other proteins, namely $\beta$ - and $\kappa$-casein, and could therefor play an important role in the association between casein components. The sensitivity of TSF was demonstrable after heat treatment to $90^{\circ} \mathrm{C}$, and might remain after an ordinary pasteurization process. The turbidity of TSF was also dependent on $\mathrm{pH}$, showing a maximum at about the $\mathrm{pH}$ (at $25^{\circ} \mathrm{C}$ ) of normal milk. These facts suggest that further investigations on TSF are necessary. Unpublished results $^{4)}$ on gel filtration on TSF-preparations used in the present study revealed that the preparation still had some relatively large molecular weight material but further work will be required to understnad its nature. 


\section{Summary}

Acid casein was chromatographed on TEAE cellulose at $1^{\circ} \mathrm{C}$ and $30^{\circ} \mathrm{C}$. A temperature sensitive fraction (TSF) was obtained by rechromatography of the first eluted peak at $1^{\circ} \mathrm{C}$. There was no temperature sensitivity in the first eluted peak at $30^{\circ} \mathrm{C}$. The TSF was also recovered from $\beta$ - and $k$-casein rich fractions at $30^{\circ} \mathrm{C}$ by rechromatography at $1^{\circ} \mathrm{C}$. Protein recovery of TSF, based on the absorbancy at $280 \mathrm{~m} \mu$, was $5.1 \%$ of the applied casein. The TSF was clear in cold but turbid at a room temperature. This clear-turbid relation was reversible.

The turbidity of TSF, which was measured at $610 \mathrm{~m} \mu$, depended on the concentration and $\mathrm{pH}$ of the sample as well as temperature. Heat treatment $\left(75^{\circ} \mathrm{C} 15 \mathrm{~min}, 90^{\circ} \mathrm{C} 10 \mathrm{~min}\right)$ caused no alteration of this specific reversible clear-turbid relation. The shape of turbid material in TSF at room temperature was spherical as observed by electron microscopy. The tyrosintryptophane molar ratio of TSF calculated from the absorption spectrum was 2.55 .

\section{Acknowldgment}

The authors express their appreciation to Mr. K. Minawa, of the Faculty of Agriculture, Hokkaido University, for his technical help in the preparation of the electron micrograph. The authors are also grateful to Dr. T. YASur, of the Faculty of Agriculture, Hokkaido. University, for his kind advice and interest in this study.

\section{References}

1) Bencze, W.L. and K. Schmid (1957) Anal. Chem., 29: 1193-1196.,

2) Groves, M.L., T.L. Mcmeekin, N.J. Hipp and W.G. Gordon (1962) Biochem. Biophys. Acta., 57: 197-203.

3) Igarashi, Y. and Z. Saito (1967) Bull. Fac. Agric. Hirosaki Univ., 13: 44-50.

4) IgARAshi, $Y$. and $Z$. SaIto Unpublished data.

5) Lauffer, M.A., A.T. Ansevin, T.E. Cartwright and C.C. Brinton, Jun., (1958) Nature, 181: $1338-1339$.

6) Payens, T.A.J. (1966) J. Dairy Sci., 49: 1317-1324.

7) Ribadeau-Dumas, B., J.L. Maubois, G. Mocquot and J. Garnier (1964) Biochem. Biophys. Acta., 82: 494-506.

8) Rose, D. and J.R. Colvin (1966) J. Dairy Sci., 49: 1091-1097.

9) Sarro, Z. and Y. Hashimoto (1964) J. Fac. Agric. Hokkaido Univ., 54: 17-41.

10) Thompson, M.P. (1966) J. Dairy Sci., 49: 792-795.

11) Wake, R.G. and R.L. Batdwin (1961) Biochem. Biophys. Acta., 47: 225-239.

12) WeBb, B.H. and A.H. Johnson (1965) Fundamentals of Dairy Chemistry 60. The AVI Publishing Co., Inc. Westport. 


\title{
カゼイン中の Temperature sensitive fraction の調製と. その二・三の性質について
}

\author{
五十嵐康雄・斉藤善一 \\ (弘前大学農学部)
}

\begin{abstract}
酸力ゼイン中に， $16^{\circ} \mathrm{C}$ で急激に白濁し，泠却すると 直々に透明となる成分，一古わち，Temperature sensitive fraction (TSF) 坊㑇められたので，その分蜼を

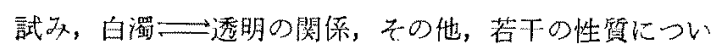
て实駼定行度つた。
\end{abstract}

新鮮脱脂孚し $\mathrm{pH} 4.6$ 沈搌物定汇別し，水洗，溶解， 再沈澱後 $\mathrm{pH} 7.7$ で溶解し, カゼイン試料とした。これ 苦 $2 \cdot$ フノ・2・メチル・1・プロパノール (AMP) 一クエン酸細衡液 $(0.027 \mathrm{M}-0.0089 \mathrm{M}, \mathrm{pH} 8.0 \sim 0.744$ $\mathrm{M}-0.255 \mathrm{M}, \mathrm{pH} 6.6)$ 定用いた凹型連続式溶出により， $1^{\circ} \mathrm{C}$ なびに $30^{\circ} \mathrm{C} て ゙ \mathrm{TEAE}$ セルロース・カラムクロ マトグラフィーを行なつた. $1^{\circ} \mathrm{C}$ の場合は，力ラムに吸 着されずに通過した最初の区分穵， $30^{\circ} \mathrm{C}$ の場合性， $\beta$ -

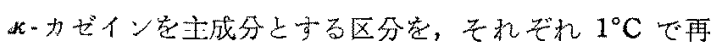

クロマトグラフィー定行ない，TSF 学分離する事が出 来た，TSFの調㬐を目的とし，力ゼイン試料 $40 \mathrm{ml}$

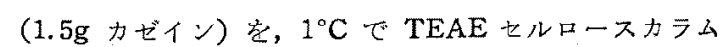
$(2.8 \times 15.0 \mathrm{~cm})$ 加ら, $0.027 \mathrm{M} \mathrm{AMP}-0.0089 \mathrm{M}$ タエン 酸緩街液のみで溶出し，同絠衝液でふたたびクロマトグ ラフィー定行なつた場合，収量は吸光度 $(280 \mathrm{~m} \mu)$ によ ればカゼインの $5.1 \%$ ，10\%トリクロル酢酸不溶性空素 によれば 4.7\% であつた。

白濁一透明の可逆性は pH 6〜10 の籍囲で観察され， 加熱 $\left(75^{\circ} \mathrm{C} 15\right.$ 分, $90^{\circ} \mathrm{C} 10$ 分)により失われなかつた。 電子顁微鏡像によれば，白濁洔恃球状粒子がみられた。 紫外線吸收スペクトルから算出したチロシン/トリプト フォン分子比は2.55であつた。 